\title{
Indigenous weather and climate forecasting knowledge among Afar pastoralists of north eastern Ethiopia: Role in adaptation to weather and climate variability
}

\author{
Mulubrhan Balehegn ${ }^{1 *}$ (D) Selam Balehey ${ }^{2}$, Chao Fu ${ }^{3}$ and Wu Liang ${ }^{3}$
}

\begin{abstract}
Traditional weather and climate forecasting is used by many indigenous communities worldwide as a guide in making important decisions that enable them cope and adapt to climate change-induced extreme weather variation. In many pastoral communities in Africa, traditional weather and climate forecasting remains the most accessible and affordable source of weather and climate information. In this study, we used individual interviews and focused group discussions to systematically document indigenous weather and climate forecasting knowledge among Afar pastoralists, with the aim of making such information available, and enhance use of this knowledge in climate change adaptation and explore synergies with modern weather forecasting system. The Afar pastoralists traditionally predict weather and climate variation through the observation of diverse bio-physical entities including livestock, insects, birds, trees and wildlife. No single indicator is taken at face value; weather forecasting is undertaken in a dynamic process where information collected from different sources, including weather information from the modern weather forecasting system, is triangulated to make the safest livelihood decisions. Before any forecasting information is used, it is evaluated through three traditional institutions that collect, share and analyse the information. These institutions include (1) the Edo or range scouting where traditional rangeland scouts are sent on a mission to assess weather and other spatially and temporally variable attributes on rangelands;

(2) the Dagu, a traditional secured and reputable network, where weather information is shared among users; and (3) the Adda or the traditional Afar governance system, which analyses traditional weather information before community decisions are made. This first-time systematic documentation of indigenous weather and climate forecasting knowledge among the Afar communities demonstrated the dynamic process of indigenous weather and climate knowledge production, analysis and communication. This shows the value of indigenous knowledge in contemporary pastoral communities, while highlighting synergies with the modern weather and climate knowledge system for co-production of knowledge that serves the objectives of local people.
\end{abstract}

Keywords: Traditional weather and climate forecasting, Afar, Pastoralists, Ethiopia

\footnotetext{
* Correspondence: mulubrhan.balehegn@mu.edu.et

'Department of Animal, Rangeland and Wildlife Sciences, Mekelle University,

Mekelle, Ethiopia

Full list of author information is available at the end of the article
} 


\section{Introduction}

Understanding, predicting and anticipating changes in weather and other climatic variables is very important for rural communities, whose livelihoods rely directly on weather and climate conditions. Local communities in the world observe climatic changes taking place in their environment which affect their livelihood choices (Nyong et al. 2007). Indigenous societies observe bio-physical animate and inanimate entities to make predictions about future and current weather variables that cannot be directly observed by the human senses (Acharya 2011).

However, in many indigenous pastoral communities in Africa, factors such as land and natural resource dispossession (Balehegn 2015), state policies that favour centralization at the expense of bio-regionalism (Fratkin and Roth 2006; McGinnis 2005) and globalization (Gilberthorpe and Hilson 2014) have resulted in generational degradation and decline in the use of indigenous weather forecasting and other traditional knowledge. Similarly, climate change and associated increase in weather variability, especially in the arid and semi-arid ecosystems (Sivakumar et al., 2005), have resulted in decrease in the reliability of many of the traditional weather forecasting knowledge systems; as a result of this, many indigenous people are abandoning the use and generational transmission of such knowledge (Roncoli et al., 2011, Kalanda-Joshua et al. 2011, Kagunyu et al. 2016). Similarly, the Afar traditional pastoral production system in the Horn of Africa has been continuously under threat from climate change (as manifested by increased recurrent drought and extreme variability) and non-friendly pastoral state policies (Balehegn 2016).

Despite the loss of indigenous weather forecasting knowledge, there is also a very limited shift towards the use of modern weather forecasting and climate information systems among many African pastoralists. This is mainly due to the many limitations of modern weather forecasting and climate change information when it comes to its application and use in pastoral societies. These limitations include the following: (1) Modern weather forecasting information is usually not accessible to pastoralists, since they do not have access to modern communication media channels (Shoko and Shoko 2013). (2) Even when they have access to the information, it is difficult for pastoralist communities to interpret and use this information, as many of Africa's pastoralists are not well-versed with the sciences and language skills used to relay the information (Shoko and Shoko 2013). (3) The cost incurred while buying facilities and during the installations of modern weather forecasting systems is quite high; as a result, such facilities are limited to urban areas where they could be easily maintained. (4) Understanding day-to-day climate conditions is very important to the pastoralists as it guides their daily activities; this makes it important at all levels, that is, at the villages, districts, rangeland and urban centres. Therefore, even when it is accessible, affordable and correctly interpretable, conventional weather forecasting information is seldom relevant to the daily decision-making of pastoralists (Chisadza et al. 2015).

Because of the challenges of applying modern climate knowledge systems, indigenous knowledge on climate and weather forecasting not only is relevant but also continues to be the only accessible and affordable alternative source of climatic information among many pastoral communities in Africa (Chisadza et al. 2015; Green et al. 2010). Indigenous climate and weather forecasting knowledge provides information and insights that can be used for successful adaptation to climate change at the local level (Chisadza et al. 2015). Many studies comparing indigenous and modern weather and climate forecasting knowledge have found a positive correlation between indicators used by indigenous and modern science (Chisadza et al. 2015). These studies inevitably recommend the co-production of weather and climate knowledge by the two knowledge systems (i.e. indigenous and modern) and the creation of a system which synergizes the accuracy of the modern systems as well as the local relevance of the traditional systems (Kalanda-Joshua et al. 2011).

The objectives of this study were therefore to understand and develop a theoretical framework for understanding indigenous weather forecasting; to document the indigenous weather and climate knowledge production, analysis and communication among Afar pastoralists in north eastern Ethiopia; to investigate the role of customary institutions in indigenous weather forecasting among Afar pastoralists; to identify the different bio-physical observations made for weather forecasting among Afar pastoralists; and finally to elucidate the role of such indigenous knowledge in local adaptation to climate change and extreme weather variability and explore synergies with the conventional system.

\section{A theoretical framework for understanding indigenous weather and climate knowledge production among Afar pastoralists}

The Afar pastoralists live in the dryland rangeland areas and have routine interaction with the natural environment which gives them opportunities for observing subtle changes in the environment that cannot be detected by modern data acquisition techniques. Weather data or information in Afar is traditionally collected by individual Afar, like the principles of citizen sciences or crowd sourcing of information (Wiggins and Crowston 2011). Bio-physical entities in the environment such as migration patterns of birds (Richardson 1990), changes in the reproduction behaviours of insects, characteristics of winds and constellation of celestial bodies all provide practical 
proxies for weather and climate (Acharya 2011). Though Afar pastoralists cannot directly measure the weather variables, they can directly observe the bio-physical manifestations with their senses (Chisadza et al. 2015). The interpretation of these bio-physical variables is therefore used as a proxy for weather change and variation (Fig. 1).

In Fig. 1, it is important to note that the first arrow is two-directional, which means that sometimes observable bio-physical entities could be results as well as indicators of impending or already-happening change in weather variables. Therefore, what local people observe could be both because of weather change that has already taken place or is taking place and an indicator of what is going to happen soon. For instance, the flowering of a tree could be due to the increase in humidity that is detectable or accessible only by the tree (Speranza et al. 2010), but for local communities, it is an indicator of future weather that humans cannot detect at the present. In another way, observable entities, such as the direction of wind, could be the cause of an impending change in weather or climatic variables (Gearheard et al. 2010). In the second arrow, people observe these bio-physical proxies of weather and climate and collect data, which they then use to make predictions through the path of the third arrow. The third arrow is, however, double to indicate that whether the prediction was successful or not will provide a feedback to the community to refine their knowledge by providing another feedback (fourth arrow), on which indicators to follow or use in the future.

The production, accumulation and transmission of indigenous weather forecasting knowledge should therefore be understood as a dynamic process where Afar pastoralists not only record observable changes and try to associate with the results or happenings (arrows 2 and 3, respectively), but also get feedback from a continuously changing relationship between observable bio-physical variables and un-observable changes in weather, so as to continuously update and improve their knowledge (Sillitoe 2007). After repeated observations of bio-physical proxies and the events that seem to follow or be associated with these observations, local communities construct or propose a relationship the type A causes $\mathrm{B}$, but also continuously observe this relationship for any changes. For example, if at times A does not cause $B$ or rather causes $C$, then people readjust their interpretation accordingly. After repeated observations, predictions, feedbacks and readjusting relationship cycles, then people can safely predict even the least detectable future outcomes, with a higher level of confidence (albeit not quantified). All forms of outcomes including a rainy season, a drought and a windy season are considered as good lessons that help the Afar to be better attuned with their environment and make them more and more capable of understanding and predicting future weather and climate events. Every event is a learning opportunity. The Afar have a proverb that signifies this. The Afar say Dabal kal daha moka roughly meaning 'the tribulations that you had to endure during drought, are compensated by the lessons of survival you learn'.

This implies that local people are not rigid followers of only one system; rather, they select systems that are accessible and effective for a given condition, including information from modern weather forecasting. Therefore, with the increased unreliability of traditional bio-physical indicators, many indigenous communities are modifying their strategies and actively seeking information from the modern weather forecasting sciences (Roncoli et al., 2011). In the Afar pastoral areas,

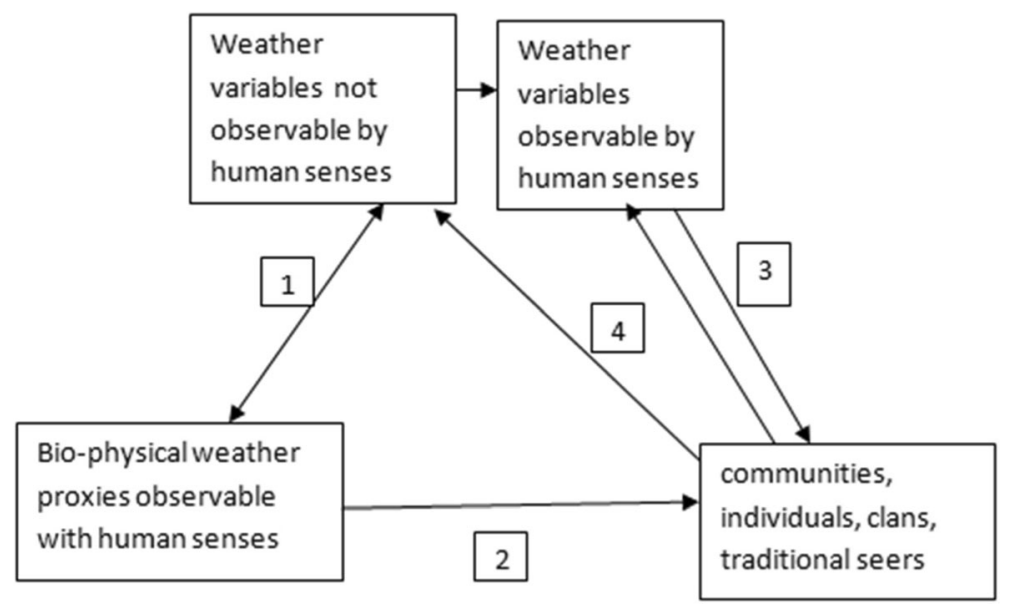

Fig. 1 Schematic presentation of the production of weather forecasting knowledge among Afar pastoralists (numbers are the order in which the dynamic takes place) 
modern weather forecasting information is actively sought through the local radios and government news media. People, however, do not take the information directly and have to make a lot of comparisons with local conditions and local bio-physical observations. Therefore, indigenous weather forecasting in principle is similar to scientific meteorology where current observable variables are used to predict future events (Gearheard et al. 2010).

\section{Study area}

The study was carried out in Ab'alá district of the Afar regional state of Ethiopia which is located at $13^{\circ} 00^{\prime}$ to $13^{\circ} 45^{\prime} \mathrm{N}$ and $39^{\circ} 40^{\prime}$ to $40^{\circ} 12^{\prime} \mathrm{E}$ (Fig. 2). According to official data, the total population in the district is 35,443 inhabitants with 2683 pastoral households and 3226 agro-pastoral and mixed farming households (BoPRD 2008). The Afar and the Tigrians are the two dominant ethnic groups in the study area. The Afar community economic activities include pastoralism, crop production, petty trade and migrant labourers; the Tigrians are mainly agro-pastoralists with crop production as a primary source of livelihoods (Balehegn and Tafere 2013).

The Abalá district is characterized by arid and semiarid climate with vegetation groups identified as desert and semi-desert scrub land (Friis et al. 2010). The total area of land in the district is 172,181 ha containing 24,177 ha of rangelands, 9,339 ha of forest and 128,712 ha of barren desert (Balehegn and Tafere, 2013). There are 9,636 ha of cultivated land under rain-fed cultivation and 15 ha under irrigation with maize, sorghum, teff and barley being the most common crops. The livestock population included 44,605 cattle, 38,306 sheep, 87,352 goats, 28,834 camel, 4841 equines and 2564 poultry (BoPRD 2008).

\section{Materials and methods}

Focused group discussions, individual interviews, a feedback workshop and a review of relevant information were used to collect information on the general indigenous weather forecasting knowledge, the process and information collection, the role of customary institutions and the various bio-physical and social variables used for weather forecasting. Six focused group discussions, each having six participants which included community leaders, elderly men, elderly women, clan leaders, herders and local pastoral and agricultural office personnel, were held to collect general information on the knowledge and process of indigenous weather forecasting. Participants in the focus group discussions were selected based on their experiences in traditional weather forecasting. For instance, all the six members of the groups deliberately included people who had extensive experience in herding and $E d o$ or traditional rangeland scouting. Individual interviews were held with members of the households to collect more detailed information on the type of indicators local people use for predicting weather, the process of weather prediction and the role of customary institutions and traditions in predicting weather. After interviewing 80 households, no new information was obtained; thus, we stopped the interview after 85 respondents.

Information collected from different individual interviews and focused group discussions was typologically categorized into various categories such as indicators, prediction results and analysis. Results were then presented to a special group of people who were perceived to have good information on indigenous weather forecasting. This category of people was selected during the household interviews. This special group included four traditional weather forecasting seers, five clan

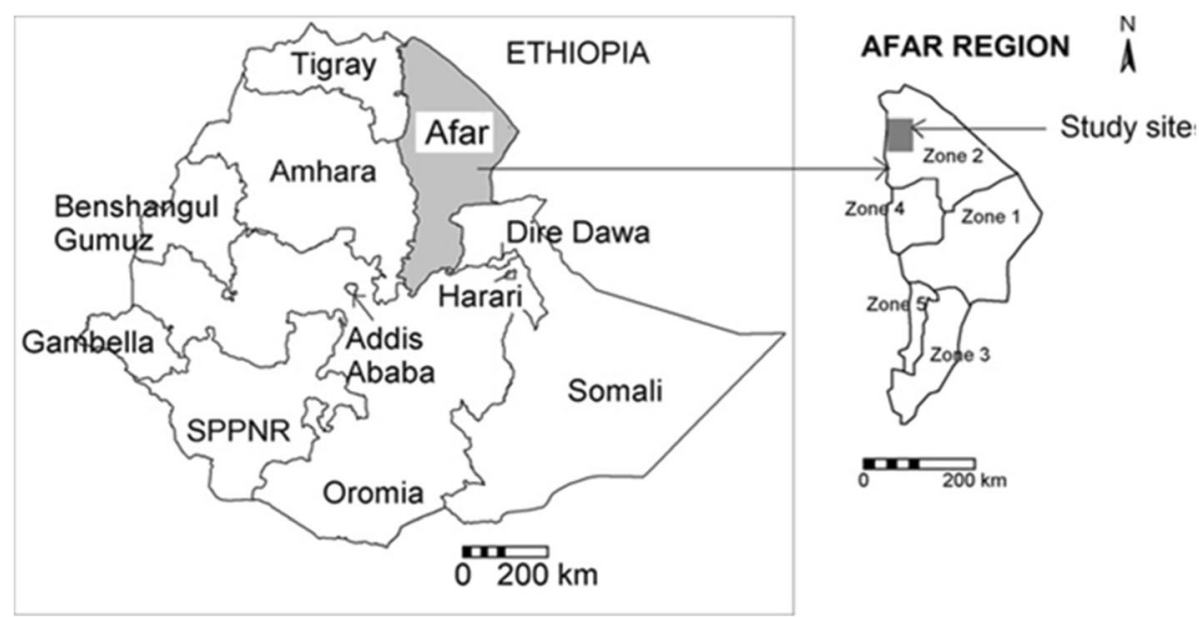

Fig. 2 The location of the study is the Aba'ala district, relative to the Afar regional State, zones within the Regional State and Ethiopia 
leaders, three elderly women and young herders, to ascertain and affirm that the information acquired was true and hence was suitable for the final presentation or documentation.

\section{Results and discussion}

Traditional weather forecasting and the role of customary institutions

The Afar pastoral communities have long established customary institutions and traditions which are involved in weather forecasting, communication and use of weather information. These institutions include the following: (1) the Adda or a traditional Afar administration system, led by Asayamaras or Afar elders who are respected and trusted by the community members and who direct and lead almost all parts of life of the Afar pastoral communities (Hailu et al. 2008); (2) the Edo or the traditional range scouting practised whenever the Afar pastoralists are faced with the prospects of unpredictable future weather, which then send rangeland scouts or Edos. The Edos are usually strong young men who are sent to places to collect information about weather, rangeland conditions, local politics and other information relevant to the livelihoods of pastoral communities (Tesfay and Tafere 2004). The individuals sent for rangeland scouting (Edo) make detailed observations about the plants, soil, atmosphere, conditions of animals, constellation of celestial bodies, etc. (Table 3); and (3) the Dagu which is an effective and reputable traditional human-based information and knowledge sharing network, through which anything anywhere that is relevant to the pastoral life of the Afar is made to reach to relevant individuals and households (Moges 2010).

Observation is made on special plants, insects, birds and environment to reach a conclusion about the future weather conditions in the rangeland they visit. The scouts in Edo actively seek information from people of many locations. Whenever the people in Edo meet anyone from any direction, they always do the customary ritual of Dagu. Dagu people who just met exchange the customary greeting of Aselam Wealikum and Wealiku Aselam. Those in Edo then usually start by asking what have your eyes seen and your ears heard?' and continue asking a meticulous list of questions to the stranger. Who are you? Where are you from? Where are you going? What is happening there? How is the weather now (and in the future)? What is the reason for that kind of weather prediction? Whose animals are where? What is the security situation? Who said so? How? Why?, etc., are just some of the questions the people in Edo ask to extract information about weather, pastures and politics of distant rangelands (Moges 2010). During Dagu, every Afar has a tribal obligation to transmit credible information without any reservation or limitation (Moges 2010). In cases where someone does not have the original source of information, he must cite the person from whom he got the information (Moges 2010). The Afar pastoralists trust and depend on information obtained from Edo and Dagu because, as people who are strong adherents of the Adda ruling, misinformation has serious consequences, not only to an individual, but also to an entire clan to which the individual belongs, who will be forced to pay compensations of a large number of camels to the victims of misinformation. Therefore, the Dagu is made falsehood-proof through an effective and strong circular feedback system in the Adda (Moges 2010).

The role of the Adda administration or its elders is usually in the interpretation and determination of the practical implication of different weather prediction scenarios. The Adda elders collect information from various sources including their own observation, consultation of traditional seers and even information from the formal State weather forecasting services. The Adda elders then triangulate information from different sources and formulate the most probable weather scenarios and give the most suited decision for each scenario regarding migration routes and destinations for migrating families. However, no prediction is taken for granted, and uncertainty is identified and declared. During the Adda discussions, the word and the concept of Inshalah or 'if God wills' is repeatedly uttered and applied. They recommend community actions based on the probability of each weather forecast, with the most probable always considered first for making decisions. Figure 3 is a schematic outline of the weather information collection, analysis and decision-making by the Afar Adda elders.

If for instance, during an ongoing drought, rain is predicted to come soon (within a time of 6 months) and if abundance is predicted, the Adda elders advise their community members to stay around and may even start planning celebrations, festivities and marriages. However, in the meantime, the households are advised to undertake different courses of actions that will help them survive the existing drought. These actions include collecting and storing famine foods such as wild seeds and fruits, selling of dry or unproductive animals, purchasing of grains, temporarily migrating to nearby better-off villages and getting loans (money, grains or animals) from relatives or friends in other places or production systems. Households with an already suckling camel calf, for example, are usually advised to sacrifice their calves, a practice locally called making of kibu or sacrificed calf, so that the milk produced by the camel will be exclusively for human consumption and be enough for children (Balehegn 2013; Balehegn 2016).

In cases when there seems to be no hope for the coming of the rains in the near future (a period that can last up to 2 to 5 years), the $A d d a$ elders gather the household heads and advise them on the best course of action to take, which is usually destocking or selling of all animals, 


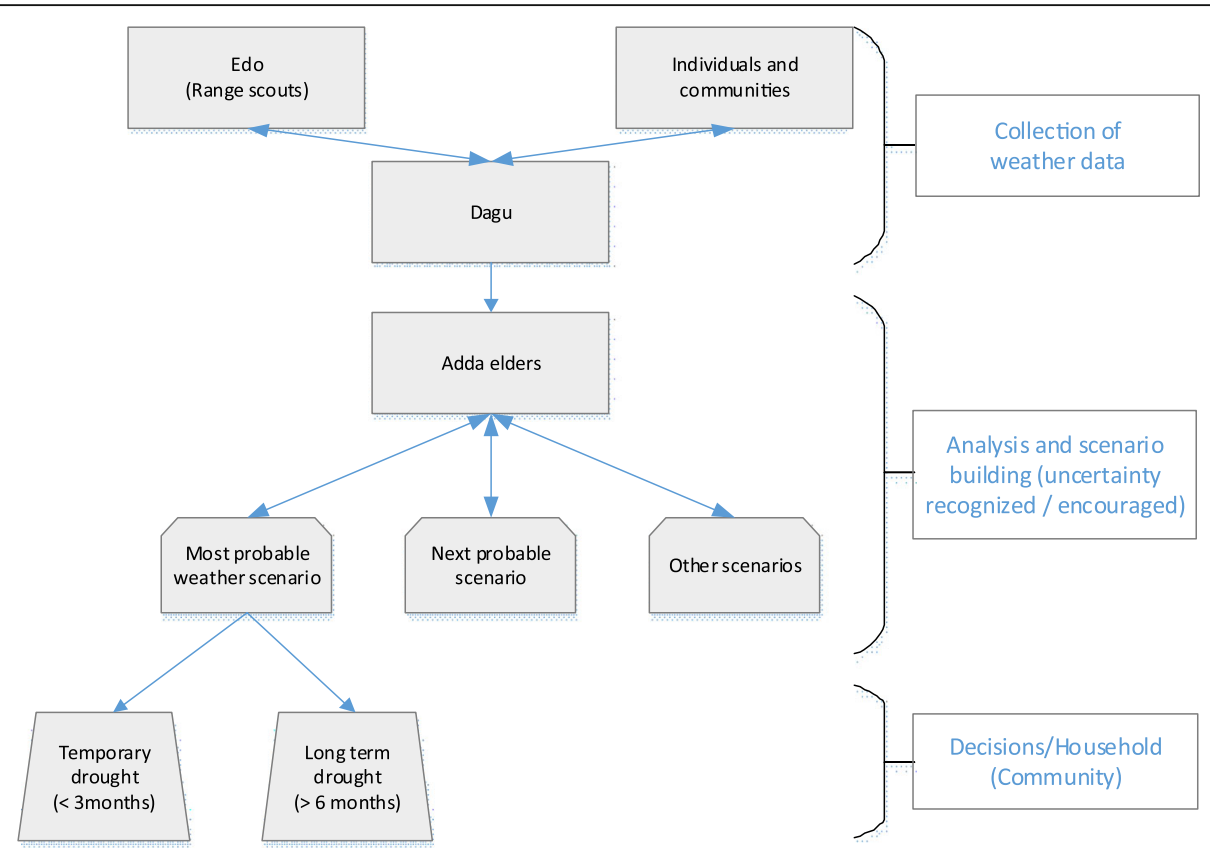

Fig. 3 Collection, interpretation (analysis) and decision-making based on tradition weather forecasting information in the Afar pastoral areas (line arrows indicate the flow of information; solid arrows indicate interpretation or decision)

slaughtering animals and storing dried meat, purchasing of grains and migrating to the nearest safest rangelands that will provide the community and their herds with enough forage and water.

\section{Traditional rain calendar of Afar pastoralists}

The Afar traditionally identify seven rainy periods, namely, Konayto, Datrob, Debaba, Deda'e, Segum, Karma and two periods of Gilal (the cold period) and Hagaya (the hot period) (Table 1). Each of the rainy periods is associated with a certain month or months. Today, however, such a meticulous classification is disappearing, and hence, some of these seasons are not known particularly to the younger generations (Balehegn and Kelemework 2013). Understanding the rainy calendar is an integral part of traditional weather forecasting and the associated livelihood decision-making. The Konayto rain is the first rain that is observed after the Ethiopian New Year (which usually falls on 11 September). In Afar folklore, the Datrob rain is considered a sign of strength and virility. In one verse of the Afar traditional praise of the camel, the female camel's beauty and the male camel's strength are equated with the Datrob rain, i.e. dark in complexion for the female camel and strong and aggressive for the male camel (Balehegn 2016). Gilal, which means a cold and dry time in Afar, by itself is not a season but a collective name given to all seasons falling between the months of December and March, which are characterized by relatively colder or lower temperatures compared to the other seasons. The time of Gilal therefore spans from the season of Debaba and Deda'e and some time in the season of Segum. This means that it can be Gilal while it is Segum or Debaba or Deda'e. Hagaya, like Gilal, is not a season by itself but rather a collective name given to all seasons falling between mid of March and mid of June. It literally means hot time, or time when the temperatures are higher. Hagaya therefore spans between the seasons of Segum and Karma. Therefore, it can be called Hagaya while it is Segum and Karma. Segum is an important rainy season, but still is less important than the main rainy season that is Karma. Complete description and timing of each of the rainy seasons is given in Table 1 .

\section{Bio-physical variables used by Afar pastoralists for weather prediction}

The Afar pastoralists, through centuries-old experiential knowledge, passed to generations by word of mouth, have developed elaborate strategies for forecasting weather and climate from observable changes in bio-physical variables in their environment. Such traditional weather forecasting strategies are common among many indigenous communities across the world and are an essential part of the livelihood strategies, as they appear to be usually the only accessible and understandable weather information to local people (Masinde and Bagula 2011). The Afar predict the condition of rain, at a specific season or anticipated season, basing on the observation of bio-physical entities such as trees, animals, winds and celestial bodies. Such bio-physical indicators of the rain in each rainy season, 
Table 1 Traditional Afar rain calendar and description of seasons

\begin{tabular}{|c|c|c|c|c|}
\hline \multirow[t]{2}{*}{ Division of seasons } & & \multicolumn{2}{|l|}{ Timing and duration } & \multirow[t]{2}{*}{ Description of seasons } \\
\hline & & Timing & Duration & \\
\hline & Datrob & 7-12 October & 1 week & $\begin{array}{l}\text { In Afar language, Datrob literally means the dark rains and it is because } \\
\text { the rain is preceded by very dark and heavy clouds. It is usually windy } \\
\text { and destructive, albeit being an important rain for increasing grass } \\
\text { cover and brow growth. }\end{array}$ \\
\hline \multirow[t]{3}{*}{ Gilal } & Konayto & 27 October to 3 November & 5 days & $\begin{array}{l}\text { The term Konayto in Afar means only } 5 \text { days and signifies the fact } \\
\text { that this rain stays only for } 5 \text { days. This is a very light shower that } \\
\text { marks the end of the rainy season. This is characterized by the } \\
\text { replenishing of leaves of certain species which have shaded their } \\
\text { leaves during the previous heavy rains. }\end{array}$ \\
\hline & Dababa & 11 November to 9 December & 1 month & $\begin{array}{l}\text { The term Dababa in Afar means additional or supplementary, which } \\
\text { indicates that the rain is considered as a supplement to the long rainy } \\
\text { season which ended with Konaytu rains. The season is characterized } \\
\text { by misty and cloudy conditions and not noticeable rain. }\end{array}$ \\
\hline & Deda'e & December to January & 1 month & $\begin{array}{l}\text { Deda'e is a name given to a generally cold season. There is not much } \\
\text { rain, but there is plenty of cold dew and misty and foggy sky. }\end{array}$ \\
\hline \multirow[t]{2}{*}{ Hagaya } & Segum & 29 March to 23 May & 2 months & $\begin{array}{l}\text { This is considered the second most important rainy season, next to } \\
\text { the Karma or the main rainy season. The term Segum, in the Afar } \\
\text { language, means a time of merry, satisfaction and abundance of } \\
\text { creamy milk. This is because, when the Segum is good, it means } \\
\text { animals and people have to endure only a very short period of dry } \\
\text { season; as a result, there will be a lot of produce. The rains in this } \\
\text { season are usually very strong with a lot of thunder and lightning. }\end{array}$ \\
\hline & Karma & June to September & 4 months & $\begin{array}{l}\text { Karma is the main rainy season. The rain starts as heavy and stormy } \\
\text { rains during early to mid-June, peaking during the month of July and } \\
\text { continuing with lighter and lighter showers during the month of August } \\
\text { and very limited and declining rains during early to mid-September. }\end{array}$ \\
\hline
\end{tabular}

the time they are observed, and the implication or interpretation of observations are given in Table 3.

\section{Observation of variation in tree phenology}

Certain plants in Afar reveal some changes as a result of impending weather conditions. These include trees that bloom in expectation of upcoming rain such as Acacia tortilits (Eepto), Acacia senegal (Tikibleyta), Tearto ${ }^{1}$ and Acacia melifera (Merkaeto) (Table 3). The blooming in anticipation of rain observed in these plants can be explained by the 'environmental prediction' hypothesis, which states that plants are naturally capable of predicting future weather, an evolutionary characteristic for better reproductive success, where flower and fruit production is synchronized with resource-abundant seasons (Sakai 2002; Williamson and Ickes 2002). Some trees such as Dobera glabra (Gersa), which is usually a normally dull greyish local plant, turns deep green and produces more shoots, fruits and seeds, with expected failure of rains in the Segum season. Similarly, Adansonia digitata (Gabita), which usually stays leafless most of the year in the Afar landscape, produces more leaves and fruits, when drought or failure of rains is expected, an observation also reported by Speranza et al. (2010) for other locations. Therefore, the response of change in trees varies from species to species and place to place. This is because the characteristics of trees and shrubs, as affected by climate or weather variables, are also dependent on other factors such as topography, edaphic and other habitat factors (Rathcke and Lacey 1985). Generally, these observations deserve further detailed ecological studies to understand the scientific underpinnings of the use of each tree and extract implications that might have importance in many fields of science (Speranza et al. 2010; Shoko and Shoko 2013).

\section{Observation of animal behaviour}

The Afar pastoralists also predict specific weather based on observation of changes in animal behaviour at certain specific periods of time. These observations include change in plumage of birds, reproductive and browsing behaviour of camels and the behaviour and movements of insects, foxes and other wildlife (Table 3). Animals are known to have instinctive capabilities of sensing and detecting subtle changes in environmental variables and anticipate different natural events including climatic and geological events, thereby changing their behaviours including reproduction, migration and feeding, to adapt to the expected changes (Acharya 2011). Many species in the animal kingdom, according to the mismatch hypothesis (Dunn et al. 2011), have evolved to respond to expected increase in resource abundance by increasing 
their reproduction behaviour. The Afar pastoralists therefore understand sudden increase in libido, fertility and other reproductive behaviour of animals and the exhibition of comfort, satisfaction, delight and playful behaviour as signs of the coming of rains, as have been reported in other indigenous people (Zuma-Netshiukhwi et al. 2013). On the other hand, signs of distress and discomfort indicate an impending danger such as flooding or drought (Kagunyu et al. 2016). Similarly, a wide variety of birds change their plumage, reproductive and migration behaviour in anticipation of change in seasons (Acharya 2011). For instance, a starling species locally called Wadartailoli changes its plumage into deep glossy blue, when a good rain is expected; otherwise, it would be greyish in plumage. The different birds and their behaviour as indicators of weather change are given in Table 3.

Insects, similar to other animals, also undergo modification in their reproductive, feeding and other behaviours according to anticipated weather change (Costa Neto 2006; Pellegrino et al. 2013). Therefore, the Afar also observe the behavioural changes of various insects, mainly ants and beetles, and use these observations to predict weather. While the details of the different insect observations are given in Table 3, an elaborate case of a local black ant species called Dakura ant or the 'jump about' ant is used by women involved in fetching water for predicting the coming weather. Women gather around the water wells and do an experiment by scratching an artificial ditch in front of an army of Dakura ants. They observe the way the ants go. If the ants move inside the ditch or cross the ditch, then it is considered that the next rainy season will be dry. However, if the ants avoid the ditches and rush to go roundabout without directly crossing or getting inside the ditches, then this is an indicator of a good rainy season coming. This experiment is described in a schematic presentation (Fig. 4). Though at this point, it might be difficult to give a scientific explanation on what is happening in this 'ant-rout experiment', the explanation according to the Afar community, is that the ants are trying to avoid the ditches, because they have instinctively sensed rains or floods and are trying to avoid being washed away.

\section{Observation of celestial bodies}

The Afar make an observation of changes in the pattern and constellations of different celestial bodies including the sky, the sun, the moon and different stars to extract information about the upcoming weather. Such observations of celestial bodies in search of clues on weather and climate are very common among indigenous people (Shoko and Shoko 2013; Speranza et al. 2010; Elia et al. 2014).

Celestial bodies observed include the constellation of different stars; colour change in the sky, the sun and the moon; and direction and timing of the crescent (Table 3). Of all these, the observation of the constellation of stars is the most elaborate one, with the Afar traditionally identifying and describing three distinct types of stars, namely the Dohra, the Kaihima and the Malhino.

The Dohra star is a lone bright star that symbolizes beauty in Afar. It is observed during the month of the third to fourth of Mawlid (this date always varies in the Gregorian calendar). The Kaihima stars are a group of seven stars which are said to be observable mainly to camels. These stars show up during the Hagaya season (April, May, June). The Malhino stars are a group of seven stars (the Big Dipper?) arranged in such a way that three stars are lined up to follow the four stars set in a rectangular form. The different observations of the constellation of stars and their weather-related indigenous interpretation are given in Table 3.

\section{Observation of winds}

Variation in nature of the wind has been used by traditional societies as an indicator of weather change since time immemorial (Jiri et al. 2016). The Afar observe the direction, strength, force and duration of winds that blow at different seasons and use these as sources of information for predicting weather. The Afar describe

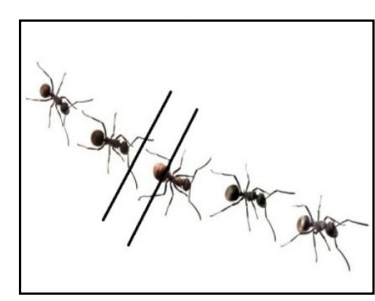

A

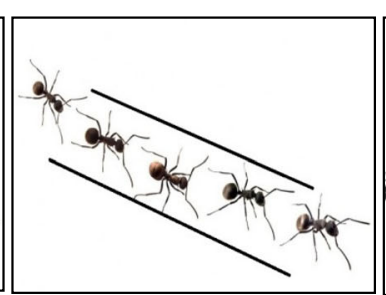

B

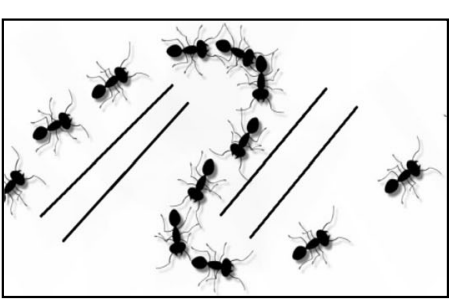

C

Fig. 4 Scenarios in the ant-rout experiment. Three scenarios of the 'ant-rout' experiment for predicting rains (parallel lines are artificially constructed ditches). a Ants cross ditches, indicating the coming of drought. $\mathbf{b}$ Ants go through ditches, indicating there will be good rain. c Ants going in roundabouts or zigzags to avoid ditches, indicating it will be rainy 
Table 2 Winds and their characteristics as described by the Afar pastoralists

\begin{tabular}{|c|c|c|}
\hline Wind & Timing & Characteristics \\
\hline Gilalta & Segum season & $\begin{array}{l}\text { These are winds that blow from north } \\
\text { to south during the hottest part of the } \\
\text { year (Gilal). }\end{array}$ \\
\hline Burantu & & $\begin{array}{l}\text { This is also called the wind of greyness or } \\
\text { drought and blows from the east to west. } \\
\text { It is also termed as infertile wind or wind } \\
\text { that does not result in any form of grass } \\
\text { productivity or plant growth. }\end{array}$ \\
\hline Woreru & November & $\begin{array}{l}\text { Very weak winds blowing from north to } \\
\text { west and brings clouds on November }\end{array}$ \\
\hline Kuya & Late May & $\begin{array}{l}\text { A wind that blows from western highlands } \\
\text { to east and signals the start of Karma }\end{array}$ \\
\hline Silayto & June & $\begin{array}{l}\text { Strong silayto winds blowing, with a whizzing } \\
\text { sound from the western highlands to the Afar } \\
\text { hinterland }\end{array}$ \\
\hline Kilb & Segum season & $\begin{array}{l}\text { Wind that flows from south to north and is } \\
\text { an indication of strong and devastating } \\
\text { Segum rains }\end{array}$ \\
\hline
\end{tabular}

and characterize six types of winds based on the timing, direction, strength, etc. These winds include Gilalta, Burentu, Woreru, Kuya, Silayto and Kilb (Table 2). Each of these winds has specific characteristics and is used to describe the condition of rain in different rainy seasons as indicated in Table 3.

\section{Exploring synergies with modern weather and climate forecasting system}

Recognizing the unique values of both modern and traditional weather and climate forecasting systems, various researchers (Armatas et al. 2016; Sanni et al. 2012; Jiri et al. 2016) opted for finding synergies that would enable the co-production of weather and climate forecasting knowledge by the indigenous and modern forecasting systems. However, apart from showing similarity and correlation between the two knowledge systems and giving the inevitable recommendations of 'integrating' indigenous and modern system, many researchers failed to show a practical approach for the synergetic use of the two knowledge systems.

The lack of a practical approach for integrating or synergetic use of the indigenous and traditional knowledge systems arises because of the challenge posed by the use of different 'data' or format of knowledge used by the two knowledge systems (Agrawal 2002). Fortunately for the Afar indigenous weather and climate forecasting knowledge, not only are most of the bio-physical indicators or data collected 'recordable' and 'analyzable' by scientific approaches, but they are also similar to modern science as shown in Fig. 3. According to the Afar traditional system, the Afar Adda elders, who do the analysis of weather and climate data, depend on multiple indicators, including data or information from modern weather forecasting services. Therefore, the first entry point for the synergetic hybridization of the two knowledge systems would be to increase the accessibility of modern weather forecasting information for the whole community and most importantly for the Afar Adda elders. Moreover, the national meteorological bureau of Ethiopia or the Afar Regional State should closely supervise the use of their data by local communities and obtain feedback on whether the data from the modern stations is in agreement or not with local indicators and the predictions made by local people. This would allow adjustments to be made, by both systems, to improve the accuracy of forecast using the hybridized system. Such a co-production of forecasting, which could be termed as a consensus forecast, has been applied successfully in Tanzania (Plotz et al. 2017). Such a system would enable the national meteorological service to enhance its usefulness for the local people.

Apart from consensus forecast which utilizes coproduction of weather and climate information, it is also possible to produce indigenous weather forecasting data or information in formats that are amenable to the statistical tools used by the modern system. This approach converts indigenous weather forecasting indicators into recordable or measurable data, to produce indigenous knowledge database (Chambers et al. 2017). In the case of Afar pastoral communities, the database can be directly developed by the local communities, or Adda elders, using a system of recording, perhaps, a simple phone application or other similar recording tool. The developed data can then be transferred into the modern weather forecasting stations to help develop a prediction based on the combined data from modern stations and indigenous knowledge.

Regardless of which approaches are used, however, it should be noted that indigenous knowledge exists regardless of whether it is suitable for analysis and used by modern methodologies. Therefore, suggested approaches should not by any means obliterate the cultural contexts and values of indigenous data (Chambers et al. 2017). Even when indigenous knowledge does not agree with scientific prediction, it is counterproductive to discard, discredit or change the knowledge. Any change or modification of the indigenous knowledge system should come only through a socio-cultural context-specific change initiated by no other than the indigenous people who are the rightful owners of the knowledge.

\section{Conclusion}

This study has outlined the indigenous weather and climate knowledge systems, the role of customary institutions and the bio-physical indicators traditionally used by the Afar pastoralists of Ethiopia. The various indicators include bio-physical entities including livestock, 
Table 3 Season-specific bio-physical indicators of indigenous weather prediction by Afar pastoralists

\begin{tabular}{|c|c|c|c|c|}
\hline Seasons & Bio-physical indicators & Type of change observed & Period of observation & Prediction \\
\hline \multirow[t]{2}{*}{ Datrob } & \multirow[t]{2}{*}{ Animals } & $\begin{array}{l}\text { The insect locally called ka'a in } \\
\text { Afar starts stinging animals and } \\
\text { human beings }\end{array}$ & Last week of September & $\begin{array}{l}\text { Datrob rains will start within a } \\
\text { week or two. }\end{array}$ \\
\hline & & $\begin{array}{l}\text { Camels continuously and } \\
\text { repeatedly kicking their chest } \\
\text { during browsing }\end{array}$ & Mid to end of September & $\begin{array}{l}\text { Datrob rains will start soon. It is said } \\
\text { that the camels kick their chest } \\
\text { repeatedly in an effort to fend off } \\
\text { the qarma insects, which are the } \\
\text { most important indicators of the } \\
\text { coming of datrob rains. }\end{array}$ \\
\hline Konaytu & Stars & $\begin{array}{l}\text { Five groups of stars called Malhino } \\
\text { emerge in the east during early } \\
\text { morning }\end{array}$ & Mid-October & $\begin{array}{l}\text { Konaytu rains come after a week } \\
\text { time or two. }\end{array}$ \\
\hline \multirow[t]{2}{*}{ Dababa } & Sky & Misty sky observed & Early November & It will rain in Dababa. \\
\hline & Tree & $\begin{array}{l}\text { Acacia melifera (Merkaeto) trees } \\
\text { blooms }\end{array}$ & Late October & There will be rains mid-November. \\
\hline \multirow[t]{2}{*}{ Deda'e } & Sky & Misty sky & Mid to late November & $\begin{array}{l}\text { There will be Deda'e rains early } \\
\text { December. }\end{array}$ \\
\hline & Winds & $\begin{array}{l}\text { The blowing of the woreru winds } \\
\text { which blow from north to south }\end{array}$ & November & $\begin{array}{l}\text { These very weak winds bring clouds } \\
\text { and mist and cause showers during } \\
\text { the Deda'e season. }\end{array}$ \\
\hline \multirow[t]{15}{*}{ Segum } & \multirow[t]{5}{*}{ Trees } & $\begin{array}{l}\text { Normal level of flowering of } \\
\text { Dobera glabra (Gasraito) }\end{array}$ & February & Early starting and good rain in Segum \\
\hline & & $\begin{array}{l}\text { Dobera glabra (Gasraito) with too } \\
\text { much flowers and very deep } \\
\text { green leaves }\end{array}$ & February & Dry Segum or Segum rains will fail. \\
\hline & & $\begin{array}{l}\text { Flowering or blooming of Acacia } \\
\text { senegal (Tikibleyta) }\end{array}$ & February & Good rains during Segum \\
\hline & & $\begin{array}{l}\text { Flowering of Acacia melifera } \\
\text { (Merkaeto) }\end{array}$ & February to early March & Good rains during Segum \\
\hline & & $\begin{array}{l}\text { Flowering and deep greening of } \\
\text { (Salvadora persica) Adayto }\end{array}$ & Feburary & Good rains during Segum \\
\hline & \multirow[t]{6}{*}{ Animals } & $\begin{array}{l}\text { The Kala nahra or the playing on } \\
\text { the dirt and singing of foxes near } \\
\text { settlements on early mornings }\end{array}$ & February & Good Segum rains \\
\hline & & $\begin{array}{l}\text { The feather of the bird wadartailoli } \\
\text { turns in to glossy deep blue colour }\end{array}$ & February to early March & Good rains during Segum \\
\hline & & $\begin{array}{l}\text { The feather of the bird wadartailoli } \\
\text { becomes pale and greyish }\end{array}$ & February to early March & $\begin{array}{l}\text { Segume rains will fail or it will be } \\
\text { to little rain }\end{array}$ \\
\hline & & Flowering of Ureyta or alloy species & February to early March & Good rains during Segum \\
\hline & & $\begin{array}{l}\text { The Guma or the black male ostrich } \\
\text { produced a deep mu-mu-mu sound } \\
\text { throughout the day }\end{array}$ & February to early March & Good Segum rains coming \\
\hline & & $\begin{array}{l}\text { 'Red ants' going out of their nest } \\
\text { in very large numbers }\end{array}$ & Early March & Good Segum rains coming \\
\hline & \multirow[t]{4}{*}{ Stars and sky } & $\begin{array}{l}\text { Emergence of triplicate hotali stars } \\
\text { early morning in the East }\end{array}$ & Early March & $\begin{array}{l}\text { There will be good } \\
\text { Segum rains }\end{array}$ \\
\hline & & $\begin{array}{l}\text { If the hotali stars appear as a single } \\
\text { star or if not, all of them show up } \\
\text { or shows up only in pairs }\end{array}$ & Early March & $\begin{array}{l}\text { There will be drought } \\
\text { during Segum }\end{array}$ \\
\hline & & $\begin{array}{l}\text { A big lone star, called Kahima, } \\
\text { observed in the east at around } \\
\text { 4:00 AM early morning }\end{array}$ & Early March & Good Segum rains \\
\hline & & Dohora, a big 'handsome' star & March to April & Good Segum rains \\
\hline
\end{tabular}


Table 3 Season-specific bio-physical indicators of indigenous weather prediction by Afar pastoralists (Continued)

\begin{tabular}{|c|c|c|c|c|}
\hline Seasons & Bio-physical indicators & Type of change observed & Period of observation & Prediction \\
\hline & & $\begin{array}{l}\text { Dohora shows up in the east in } \\
\text { the evening around 10:00 PM }\end{array}$ & March to April & Segum rains will fail \\
\hline & & $\begin{array}{l}\text { A man milking a camel, with the camel } \\
\text { standing east head and west tail, } \\
\text { observes the lone kahima star over the } \\
\text { shoulders of the camel, during camel } \\
\text { milking early in the evening at around } \\
\text { 7:30 AM }\end{array}$ & February and March & Good Segum rains \\
\hline & & $\begin{array}{l}\text { Malhino stars, a group of seven stars } \\
\text { showing up all at once }\end{array}$ & February and March & Good Segum rains \\
\hline & & $\begin{array}{l}\text { When Malhino stars appear } \\
\text { consecutively in pairs }\end{array}$ & February and March & Segum rains will fail or will be too little. \\
\hline & & Red coloured sky in the west early & $\begin{array}{l}\text { Late January and } \\
\text { February }\end{array}$ & Good Segum rains \\
\hline & & $\begin{array}{l}\text { Coloured rings around the sun } \\
\text { or moon }\end{array}$ & February & Good Segum rains \\
\hline & & Symmetrically full moon & February & Good Segum rains \\
\hline & & $\begin{array}{l}\text { The crescent with its convex } \\
\text { side looking towards east appearing } \\
\text { around } 10-11 \text { PM in the evening }\end{array}$ & January or March & Limited rains in the Segume season \\
\hline & & $\begin{array}{l}\text { The crescent with its convex side } \\
\text { looking towards west appearing } \\
\text { around } 10-11 \mathrm{PM} \text { in the evening }\end{array}$ & January or March & Limited rains in the Segume season \\
\hline & Winds & $\begin{array}{l}\text { The Gilalta winds or the winds that } \\
\text { blow during the Gilal, or hottest } \\
\text { period, blowing from northern } \\
\text { highlands to south into the Afar } \\
\text { hinterland }\end{array}$ & November to February & $\begin{array}{l}\text { There will be good Segum rains, } \\
\text { according to the strength of the } \\
\text { Gilalta rains. The stronger the wind, } \\
\text { the better and the earlier the Segum } \\
\text { rains. Stronger Gilalta winds may also } \\
\text { cause earlier and steady Segum rains }\end{array}$ \\
\hline & & $\begin{array}{l}\text { Burahtu, the wind of greyness or drought } \\
\text { that blows from east to west }\end{array}$ & February & $\begin{array}{l}\text { This wind is said to be able to } \\
\text { disperse whatever moisture or cloud } \\
\text { that is available and causes rains to } \\
\text { fail during Segum }\end{array}$ \\
\hline \multirow[t]{7}{*}{ Karma } & \multirow[t]{4}{*}{ Tree } & Flowering of Acacis tortillis (Eepto) & Late May and early June & $\begin{array}{l}\text { Sure sign of good rain in the Karma } \\
\text { season }\end{array}$ \\
\hline & & $\begin{array}{l}\text { Flowering of Commiphora erythraea } \\
\text { (Ado-Hadit) trees }\end{array}$ & End of June & $\begin{array}{l}\text { Karma rains will continue beyond } \\
\text { the point or time on which the } \\
\text { tree flowers. }\end{array}$ \\
\hline & & Flowering of Commiphora spp. (Kurbita) & End of June & $\begin{array}{l}\text { Karma rains will continue beyond } \\
\text { the point or time on which the } \\
\text { tree flowers }\end{array}$ \\
\hline & & Flowering of Adansonia digitata (Gabita) & End of June & $\begin{array}{l}\text { Karma rains will continue beyond the } \\
\text { point or time on which the tree flowers }\end{array}$ \\
\hline & \multirow[t]{3}{*}{ Animals } & $\begin{array}{l}\text { Camels standing and gazing for a long } \\
\text { time towards the Afar hinterland and } \\
\text { insisting on travelling towards the Afar } \\
\text { hinterland and refusing to go towards } \\
\text { the west or the highlands }\end{array}$ & Late May & $\begin{array}{l}\text { Karma rains will come soon. The Afar } \\
\text { justify that the camels want to go to } \\
\text { the Afar hinterland, as they naturally } \\
\text { detect that there will be lush browse } \\
\text { soon after days, because of the rain } \\
\text { they can smell }\end{array}$ \\
\hline & & $\begin{array}{l}\text { Camels insisting on walking or travelling } \\
\text { towards western highlands, even if they } \\
\text { are led towards the eastern Afar hinterland }\end{array}$ & Late May to early June & $\begin{array}{l}\text { The Karma rains will fail and this is said } \\
\text { to make the camels to look for browse } \\
\text { in the highlands, as they detect that } \\
\text { there will not be rain in the lowlands }\end{array}$ \\
\hline & & $\begin{array}{l}\text { Excessive foam production by camel, } \\
\text { cattle and goats }\end{array}$ & Late May to early June & $\begin{array}{l}\text { Karma rains will come soon. The } \\
\text { excessive foaming is said to be } \\
\text { caused by animals browse on the } \\
\text { flowers of Acacia tortillis (Eepto), } \\
\text { which cause a lot of foaming } \\
\text { during regurgitation. }\end{array}$ \\
\hline
\end{tabular}


Table 3 Season-specific bio-physical indicators of indigenous weather prediction by Afar pastoralists (Continued)

\begin{tabular}{|c|c|c|c|c|}
\hline Seasons & Bio-physical indicators & Type of change observed & Period of observation & Prediction \\
\hline & & $\begin{array}{l}\text { Excessive singing of melodious song } \\
\text { early morning by a bird called dadohoyta }\end{array}$ & Late May to early June & $\begin{array}{l}\text { This will indicate that the Karma } \\
\text { rains will come soon and they } \\
\text { will be good. }\end{array}$ \\
\hline & & $\begin{array}{l}\text { The feathers of Wadartailoli bird turn into } \\
\text { glossy deep blue }\end{array}$ & Late May to early June & The Karma rains will be good. \\
\hline & & $\begin{array}{l}\text { The feathers of Wadartailoli bird } \\
\text { become greyish }\end{array}$ & Late May to early June & The Karma rains will fail. \\
\hline & & $\begin{array}{l}\text { A bird species called Sae'tailoli starts } \\
\text { following goats when they brow and } \\
\text { go to rivers for drinking }\end{array}$ & Early to mid-June & $\begin{array}{l}\text { Karma rains will come, or if it is } \\
\text { already raining, it will continue } \\
\text { to rain. }\end{array}$ \\
\hline & & $\begin{array}{l}\text { The Kukueta bird start singing the koda } \\
\text { or the milk churning song with a very } \\
\text { smoothly flowing tone }\end{array}$ & Early June & $\begin{array}{l}\text { The Karma rains will come and it } \\
\text { will be good, with plenty of milk } \\
\text { and milk-based food such as butter }\end{array}$ \\
\hline & & $\begin{array}{l}\text { The kukueta bird either fails to sing } \\
\text { the koda song, or when it sings it } \\
\text { will be in a half hazard and very } \\
\text { broken tone }\end{array}$ & Early June & Karma rains will fail. \\
\hline & & $\begin{array}{l}\text { The coming out of 'black ants' from } \\
\text { their nest and going in half hazard } \\
\text { way and not in straight line }\end{array}$ & Early June & $\begin{array}{l}\text { Drought or limited rains } \\
\text { during Karma }\end{array}$ \\
\hline & & $\begin{array}{l}\text { During the ant-rout experiment, the } \\
\text { black 'jump about' ants avoid running } \\
\text { or passing through artificial ditches }\end{array}$ & May and June & Good rains in Karma \\
\hline & & $\begin{array}{l}\text { During the ant-rout experiment, the } \\
\text { black jump about ants run or pass } \\
\text { though the artificial ditches }\end{array}$ & May and June & $\begin{array}{l}\text { Drought or failure of rains in } \\
\text { the Krama }\end{array}$ \\
\hline & & $\begin{array}{l}\text { Too many black beetles (dung beetles) } \\
\text { collecting dung rolls }\end{array}$ & Early to mid-June & $\begin{array}{l}\text { There will be good rains during } \\
\text { the Karma season. }\end{array}$ \\
\hline & Wind & $\begin{array}{l}\text { Kuya, a wind that blows from west } \\
\text { (highlands) to east in the Afar hinterland }\end{array}$ & Late May to early June & Karma rains will soon start. \\
\hline & & $\begin{array}{l}\text { Strong silayto winds blowing, with } \\
\text { a whizzing sound from the western } \\
\text { highlands to the Afar hinterland } \\
\text { Weak Silayto winds }\end{array}$ & May and June & $\begin{array}{l}\text { Stronger winds indicate the coming } \\
\text { of good Karma rains and weaker or } \\
\text { no winds indicate no karma rains }\end{array}$ \\
\hline & $\begin{array}{l}\text { Stars, the sky and } \\
\text { moon }\end{array}$ & $\begin{array}{l}\text { Coloured rings around the sun } \\
\text { and moon }\end{array}$ & May and June & Good Karma rains will start soon \\
\hline & & $\begin{array}{l}\text { Emergence of a symmetrically } \\
\text { full moon }\end{array}$ & May & Good Karma rains will start soon \\
\hline
\end{tabular}

birds, insects, other wildlife, characteristics of winds and changes in the constellation or patterns of celestial bodies. These observations and their analysis are important to the livelihoods of pastoralists as they determine how the Afar pastoralists adapt or cope with the changing weather and climatic variations, as traditional weather forecasting continues to be the most accessible and relevant weather and climate information to contemporary Afar pastorals. The Afar pastoralists recognize the potentials and limitations of their traditional weather forecasting techniques. Therefore, no prediction information is taken at face value. Rather, the Afar, through their traditional administration system or the $A d d a$, make a triangulation of information from different sources such as weather and climate assessment missions (Edos) and traditional weather and other information communication networks (Dagu). Information collected from different sources, including formal weather information, is used to determine the most probable weather scenario of the future. Based on the most probable weather scenario, the traditional administration $(A d d a)$ then make livelihood decisions to be followed by households and entire communities. Recognizing the importance of traditional weather and climate knowledge to the livelihoods of local communities, it is recommended that use of such knowledge be enhanced by documenting these knowledge systems and identifying ways of weather and climate knowledge co-production with the formal weather and climate information. Such hybrid knowledge co-production will enable the formation of a system that 
benefits both from the local relevance of indigenous techniques and the increased accuracy and efficiency of modern techniques. Moreover, understanding the scientific underpinnings of the changes exhibited by the various plant and animal species in anticipation of weather and climate might provide important insights into the science of ecology and climate change.

\section{Endnote}

\section{${ }^{1}$ Species not identified}

\begin{abstract}
Acknowledgements
This study was funded by the Local and Indigenous Knowledge Systems (LInKS) project at the Climate Frontlines Program of UNESCO (Contract No. 4500340760-A1). Dr. Mulubrhan Balehegn was supported by the Chinese Academy of Sciences President's International Fellowship Initiative (PIFI), and Dr. Wu Liang was supported by the Natural Science Foundation of China (NSFC) (Grant No. 41401068 and 41661144022). The Climate Frontlines Program team at UNESCO, Paris, contributed through providing inputs and comments at the various stages of the study. Participants of various conferences organized by the LInKS project (Arusha Tanzania, Marrakesh Morocco, Mekelle, Ethiopia and Paris France), where preliminary findings of this study have been presented, provided important comments. We are very thankful to the field assistants at Aba'ala Afar, Mr. Hayelom Tesfay, Mr. Mohamed Nurisa and Mr. Mohamed Mistofa. We are also indebted to the many Afar elders, clan leaders and government officials who participated in the group discussion.
\end{abstract}

\section{Funding}

This study was funded by the Local and Indigenous Knowledge Systems (LInKS) project at the Climate Frontlines Program of UNESCO (Contract No. 4500340760-A1). Dr. Mulubrhan Balehegn was supported by the Chinese Academy of Sciences President's International Fellowship Initiative (PIFI), and Dr. Wu Liang was supported by the Natural Science Foundation of China (NSFC) (Grant No. 41401068 and 41661144022).

\section{Availability of data and materials}

All the available data are incorporated into the submission.

\section{Authors' contributions}

MB developed the proposal for this research, did the field work for data collection through questionnaire and focused group discussions and wrote the report and ultimately this manuscript. SB was involved as a co-investigator during the proposal write-up, the field work for data collection and the manuscript write-up. CF, as a direct supervisor of the first author, made contributions in the data collection and analysis of the write-up. CF also made significant comments on the final version of the manuscript. WL, as a cosupervisor of the first author, made contributions in the methodology, analysis and presentation of information and finally on the write-up. All authors read and approved the final manuscript.

\section{Competing interests}

The authors declare that they have no competing interests.

\section{Publisher's Note}

Springer Nature remains neutral with regard to jurisdictional claims in published maps and institutional affiliations.

\footnotetext{
Author details

'Department of Animal, Rangeland and Wild life Sciences, Mekelle University, Mekelle, Ethiopia. ${ }^{2}$ Institute of Environment, Gender and Development, Mekelle University, Mekelle, Ethiopia. ${ }^{3}$ Key Laboratory of Ecosystem Network Observation and Modeling, Institute of Geographic Sciences and Natural Resources Research, United Nations Environmental Program-International Ecosystem Management Partnership (UNEP-IEMP)', Chinese Academy of Sciences, Beijing 100101, China.
}

Received: 28 December 2018 Accepted: 15 April 2019

Published online: 28 May 2019

\section{References}

Acharya, S. 2011. Presage biology: Lessons from nature in weather forecasting. Indian Journal of Traditional Knowledge 10: 114-124.

Agrawal, A. 2002. Indigenous knowledge and the politics of classification. International Social Science Journal 54: 287-297.

Armatas, C., T. Venn, B. McBride, A. Watson, and S. Carver. 2016. Opportunities to utilize traditional phenological knowledge to support adaptive management of social-ecological systems vulnerable to changes in climate and fire regimes. Ecology and Society 21(1):16.

Balehegn, M. Encomium of the camel: the oral sung poetry of the Afar pastoralists of Ethiopia. In: Bondla, J. N., , W. B. C. S., Yoko Frusaki \& Bekerie, A., eds. Proceedings of International conference on cultural landscapes of Ethiopia, 20152013 Mekelle, Ethiopia Mekelle University Press.

Balehegn, M. 2015. Unintended consequences: The ecological repercussions of land grabbing in sub-Saharan Africa. Environment: Science and Policy for Sustainable Development 57: 4-21.

Balehegn, M. 2016. Ecological and social wisdom in camel praise poetry sung by Afar nomads of Ethiopia. Journal of Ethnobiology 36: 457-472.

Balehegn, M., and T. Kelemework. 2013. Gendered impacts and adaptation mechanisms to climate change among Afar pastoralists in north eastern Ethiopia. In Impacts of Climate Change and Variability on Pastoral Women in Sub-Saharan Africa, ed. M. Mulinge and M. Getu. Addis Ababa: Organization of Social Science Research in Eastern and Southern Africa (OSSREA).

BOPRD 2008. Afar National Regional state: Afar bureau of pastoralists and rural development (BoPRD). Basic agricultural and rural development data. July 2008. Semera, Afar, Ethiopia: Government of Afar National Regional State.

Chambers, L.E., R.D. Plotz, T. Dossis, D.H. Hiriasia, P. Malsale, D.J. Martin, R. Mitiepo, K. Tahera, and T.I. Tofaeono. 2017. A database for traditional knowledge of weather and climate in the Pacific. Meteorological Applications 24: 491-502.

Chisadza, B., M.J. Tumbare, W.R. Nyabeze, and I. Nhapi. 2015. Linkages between local knowledge drought forecasting indicators and scientific drought forecasting parameters in the Limpopo River Basin in Southern Africa. International Journal of Disaster Risk Reduction 12: 226-233.

Costa Neto, E.M. 2006. Cricket singing means rain: Semiotic meaning of insects in the district of Pedra Branca, Bahia State, northeastern Brazil. Anais da Academia Brasileira de Ciências 78: 59-68.

Dunn, P.O., D.W. Winkler, L.A. Whittingham, S.J. Hannon, and R.J. Robertson. 2011. A test of the mismatch hypothesis: How is timing of reproduction related to food abundance in an aerial insectivore? Ecology 92: 450-461.

Elia, E.F., S. Mutula, and C. Stilwell. 2014. Indigenous knowledge use in seasonal weather forecasting in Tanzania: The case of semi-arid central Tanzania. South African Journal of Libraries and Information Science 80: 18-27.

Fratkin, E., and E.A. Roth. 2006. As pastoralists settle: Social, health, and economic consequences of the pastoral sedentarization in Marsabit District. Kenya: Springer Science \& Business Media.

Friis, I., Demissew, S. \& Breugel, P. V. 2010. Atlas of the potential vegetation of Ethiopia, Det Kongelige Danske Videnskabernes Selskab.

Gearheard, S., M. Pocernich, R. Stewart, J. Sanguya, and H.P. Huntington. 2010. Linking Inuit knowledge and meteorological station observations to understand changing wind patterns at Clyde River, Nunavut. Climatic Change 100: 267-294.

Gilberthorpe, E. \& Hilson, G. 2014. Natural resource extraction and indigenous livelihoods: Development challenges in an era of globalization. London: Ashgate Publishing, Ltd. 1-281.

Green, D., J. Billy, and A. Tapim. 2010. Indigenous Australians' knowledge of weather and climate. Climatic Change 100: 337-354.

Hailu, M., Getahun, K. \& Balehegn, M. 2008. Traditional goverance systems and their operational linkage with formal governing structures in Aba'ala Wereda, Northern Afar. In: Brems, E. \& Beken, C. V. (eds.) Federalism and the Protection of Human Right in Ethiopia. Wien; Zürich; Berlin: Rect und Politik in Africa Series. 211-232.

Jiri, O., P.L. Mafongoya, C. Mubaya, and O. Mafongoya. 2016. Seasonal climate prediction and adaptation using indigenous knowledge systems in agriculture systems in Southern Africa: A review. Journal of Agricultural Science 8: 156.

Kagunyu, A., S. Wandibba, and J.G. Wanjohi. 2016. The use of indigenous climate forecasting methods by the pastoralists of Northern Kenya. Pastoralism 6: 7. 
Kalanda-Joshua, M., C. Ngongondo, L. Chipeta, and F. Mpembeka. 2011. Integrating indigenous knowledge with conventional science: Enhancing localised climate and weather forecasts in Nessa, Mulanje, Malawi. Physics and Chemistry of the Earth, Parts A/B/C 36: 996-1003.

Masinde, M., and A. Bagula. 2011. ITIKI: Bridge between African indigenous knowledge and modern science of drought prediction. Knowledge Management for Development Journal 7: 274-290.

McGinnis, M. V. 2005. A rehearsal to bioregionalism. Bioregionalism. Routledge. $15-24$.

Moges, E. Y. 2010. Dagu as a cultural regulator among the Afar people: The communication aspect. MA thesis. Addis Ababa: Addis Ababa University. 1-56.

Nyong, A., F. Adesina, and B.O. Elasha. 2007. The value of indigenous knowledge in climate change mitigation and adaptation strategies in the African Sahel. Mitigation and Adaptation Strategies for Global Change 12: 787-797.

Pellegrino, A.C., M.F.G.V. Peñaflor, C. Nardi, W. Bezner-Kerr, C.G. Guglielmo, J.M.S. Bento, and J.N. McNeil. 2013. Weather forecasting by insects: Modified sexual behaviour in response to atmospheric pressure changes. PLoS One 8: e75004

Plotz, R.D., L.E. Chambers, and C.K. Finn. 2017. The best of both worlds: A decisionmaking framework for combining traditional and contemporary forecast systems. Journal of Applied Meteorology and Climatology 56: 2377-2392.

Rathcke, B., and E.P. Lacey. 1985. Phenological patterns of terrestrial plants. Annual Review of Ecology and Systematics: 16(1), 179-214.

Richardson, W. 1990. Timing of bird migration in relation to weather: Updated review. In: Gwinner E. (eds) Bird Migrationr. Berlin: Springe. 78-101.

Roncoli C, Ingram K, Kirshen P. 2011. Reading the Rains: Local Knowledge and Rainfall Forecasting in Burkina Faso. Society \& Natural Resources 15(5):409-427.

Sakai, S. 2002. General flowering in lowland mixed dipterocarp forests of Southeast Asia. Biological Journal of the Linnean Society 75: 233-247.

Sanni, S.A., K.O. Oluwasemire, and N.O. Nnoli. 2012. Traditional capacity for weather prediction, variability and coping strategies in the front line states of Nigeria. Agricultural Sciences 3: 625.

Shoko, K., and N. Shoko. 2013. Indigenous weather forecasting systems: A case study of the abiotic weather forecasting indicators for wards 12 and 13 in Mberengwa district Zimbabwe. Asian Social Science 9: 285.

Sillitoe, P. 2007. Local science vs. global science: Approaches to indigenous knowledge in international development. New York: Berghahn Books. 1-279.

Sivakumar M.V.K., Das H.P., Brunini O. 2005. Impacts of Present and Future Climate Variability and Change on Agriculture and Forestry in the Arid and Semi-Arid Tropics. Climatic Change 70 (1-2):31-72

Speranza, C.I., B. Kiteme, P. Ambenje, U. Wiesmann, and S. Makali. 2010. Indigenous knowledge related to climate variability and change: Insights from droughts in semi-arid areas of former Makueni District, Kenya. Climatic Change 100: 295-315.

Tesfay, Y. \& Tafere, K. 2004. Indigenous rangeland resources and conflict management by the North Afar pastoral groups in Ethiopia. Drylands Coordination Group Report, Ethiopia.

Wiggins, A. \& Crowston, K. From conservation to crowdsourcing: A typology of citizen science. System Sciences (HICSS), 2011 44th Hawaii international conference on, 2011. IEEE, 1-10.

Williamson, G.B., and K. Ickes. 2002. Mast fruiting and ENSO cycles-does the cue betray a cause? Oikos 97: 459-461.

Zuma-Netshiukhwi, G., K. Stigter, and S. Walker. 2013. Use of traditional weather/ climate knowledge by farmers in the South-western Free State of South Africa: Agrometeorological learning by scientists. Atmosphere 4: 383-410.

\section{Submit your manuscript to a SpringerOpen ${ }^{\circ}$ journal and benefit from:}

- Convenient online submission

- Rigorous peer review

- Open access: articles freely available online

- High visibility within the field

- Retaining the copyright to your article

Submit your next manuscript at $\boldsymbol{\nabla}$ springeropen.com 